\title{
P162: Behavior and infection control/ influencing healthcare workers
}

\author{
PH Mishra \\ From 2nd International Conference on Prevention and Infection Control (ICPIC 2013) \\ Geneva, Switzerland. 25-28 June 2013
}

\section{Introduction}

Health care-associated infections (HAIs) have become more common $5-8 \%$ (30\% is preventable) as medical care has grown more complex and patients have become more knowledgeable and demanding.

\section{Objectives}

The objective of this study was to evaluate and suggest for improvement in Health Care Acquired infection at 150 bedded Indian Spinal Injuries Centre (ISIC).

\section{Methods}

Method included a retrospective study of HAI data for 2 years (2011-2012).

\section{Results}

Result showed that Catheter Associated Blood Stream Infection (CA-BSI) in 2011 was $0.2 \%$ \& in 2012 1.3\%. CA UTI 2011 was $3 \%$ \& in 2012 was $3.5 \%$. E.Coli $52 \%$ is main cause of Urine infections \& most sensitive to Colistin, Imipenam, Kleibsella 32\%, Pseudomonas 15\% more sensitive to Imipenam and Tazobactum.

Respiratory infection E. Coli 33\%, Staph 33\%, Acinetobacter 34\% CDC 4.8-6/1000 Ventilator days. More sensitive to Colistin.

VAP rates in ISIC in 2011 was 5\% \& in 2012 was $2.6 \%$.

\section{Conclusion}

\section{Interventions}

To be effective the infections control program has included the following:

Organized surveillance and control activities.

Two infection control Nurses have been appointed.

Medical Superintendent, Indian Spinal Injuries Centre, Delhi, India
A Trained Hospital Epidemiologist \& Microbiologist have been appointed.

A system for reporting surgical wound infection rates and other infection back to the practicing surgeons and physicians developed.

\section{UTI - Guideline}

Booklet distributed, bed side teaching is done for Catheter care, CIC Counseling, Antibiotic Catheter, VAP- Raised head end $30 \%$, Culture $1^{\text {st }}$ day $\& 3^{\text {rd }}$ Day leads to early detection and treatment.

SSI-Stopped shaving, clipping done, Chlorhexidine \& Betadine used for skin preparation.

\section{Disclosure of interest}

None declared.

Published: 20 June 2013

doi:10.1186/2047-2994-2-S1-P162

Cite this article as: Mishra: P162: Behavior and infection control/ influencing healthcare workers. Antimicrobial Resistance and Infection Control 2013 2(Suppl 1):P162.

Submit your next manuscript to BioMed Central and take full advantage of:

- Convenient online submission

- Thorough peer review

- No space constraints or color figure charges

- Immediate publication on acceptance

- Inclusion in PubMed, CAS, Scopus and Google Scholar

- Research which is freely available for redistribution 